\title{
Elemental Characterization of Romanian Crop Medicinal Plants by Neutron Activation Analysis
}

\author{
Daniela Haidu, ${ }^{1}$ Dénes Párkányi, ${ }^{2}$ Radu Ioan Moldovan, ${ }^{3}$ Cecilia Savii, ${ }^{1}$ Iulia Pinzaru, ${ }^{4}$ \\ Cristina Dehelean, ${ }^{4}$ and Ludovic Kurunczi ${ }^{1,5}$ \\ ${ }^{1}$ Institute of Chemistry Timişoara of the Romanian Academy, 24 Mihai Viteazul Bvd., 300223 Timişoara, Romania \\ ${ }^{2}$ Centre for Energy Research, Hungarian Academy of Sciences, 29-33 Konkoly Thege Miklós út, Budapest 1121, Hungary \\ ${ }^{3}$ Bio Vital Fares Laboratories, 50 Plantelor Str., 335700 Orăștie, Romania \\ ${ }^{4}$ Pharmacy II Department, Faculty of Pharmacy, "Victor Babeş” University of Medicine and Pharmacy, 2 Eftimie Murgu Sq., \\ 300041 Timișoara, Romania \\ ${ }^{5}$ Pharmacy I Department, Faculty of Pharmacy, "Victor Babes”" University of Medicine and Pharmacy, 2 Eftimie Murgu Sq., \\ 300041 Timișoara, Romania
}

Correspondence should be addressed to Iulia Pinzaru; iuliapinzaru@umft.ro

Received 23 February 2017; Revised 10 April 2017; Accepted 13 April 2017; Published 23 May 2017

Academic Editor: Miguel de la Guardia

Copyright (C) 2017 Daniela Haidu et al. This is an open access article distributed under the Creative Commons Attribution License, which permits unrestricted use, distribution, and reproduction in any medium, provided the original work is properly cited.

\begin{abstract}
The metallic elements concentrations of medicinal plants (coriander, dill, Echinacea, lavender, chamomile, mint, and plantain, used for phytopharmaceutical products), cultivated in unpolluted region, were analyzed by neutron activation analysis. The essential nutrients, macro-, micro-, and trace elements ( $\mathrm{K}, \mathrm{Ca}, \mathrm{Mg}, \mathrm{Na}, \mathrm{Fe}, \mathrm{Mn}, \mathrm{Rb}, \mathrm{Sr}$, and $\mathrm{Zn}$ ), potentially toxic elements ( $\mathrm{Al}, \mathrm{As}, \mathrm{Ba}, \mathrm{Co}$, $\mathrm{Sb}, \mathrm{Cr}$, and $\mathrm{V}$ ), and rare earth elements were monitored and were compared with those presented in the literature. An estimation of their contributions to intake and toxicity for a person was made, which revealed that (a) teas prepared from the examined plants represent useful contribution to the food provided intake of three essential macronutrients ( $\mathrm{K}, \mathrm{Ca}$, and $\mathrm{Mg}$ ); (b) the $\mathrm{Cu}, \mathrm{Mn}, \mathrm{Rb}, \mathrm{Sr}$, $\mathrm{Zn}$, and rare earths levels are normal or low; (c) the quantities of $\mathrm{As}, \mathrm{Ba}, \mathrm{Co}, \mathrm{Sb}, \mathrm{Cr}$, and $\mathrm{V}$ do not represent toxicological concerns; (d) the examination of the estimated $\mathrm{Al}$ and $\mathrm{Fe}$ quantities recovered in infusions in the conditions of usual daily tea consumption is below the Tolerable Daily Intake values. The strategy of cultivation of medicinal plants in unpolluted areas is efficient and beneficial. However, individual plants ability to concentrate preferentially certain elements suggests controlling the contamination level of raw materials.
\end{abstract}

\section{Introduction}

The preventive treatment mode and the identification of curative remedies for known diseases are not only a challenge but an imperative way to prevent and treat the evolution of possible diseases. In the development of medical advances, for a while, the discovered drugs (mostly coming from chemical synthesis) with their immediate action and desired therapeutic effects seized conventional medicine, reducing or even suppressing the influence of alternative medicine [1]. But once the chemically synthesized drug was understood in all its aspects, with therapeutic action, side and adverse effects, drug resistance, and the interactions between the active molecule and the dynamics of the human body have proved difficult to control easily. So nowadays the current trend is a return to nature, to known remedies, and among that to medicinal plants $[1,2]$. The quality of these plants, in fact the raw materials for production of teas, syrups, tinctures, capsules, or other pharmaceutic formulas, is decisively influenced by the environment (soil, nutrients, pollution, etc.) where they are growing. All these forms of pharmaceuticals based on plants are included in the category of nutritional supplements, which are not a subject to strict control. Although medicinal plants are considered harmless by ordinary people, a closer look at the risk of accumulation and control of toxic metals or undesirable elements, evaluating content items is justified and desirable to be a criterion for their use [3, 4]. If the medicinal plants are harvested from the spontaneous flora, they may 
be contaminated by heavy metals $[5,6]$ because of where they were gathered. In this context, the contamination with known or unknown pollutants raises the hypothesis of crop cultivation of the medicinal plants, in places protected from pollution, an important extra argument besides the economic issues.

Concerning the quality and safety of the herbal products, the elemental composition of the raw plant material should be a required issue. Generally, the essential nutrients $(\mathrm{K}, \mathrm{Ca}$, $\mathrm{Mg}, \mathrm{Na}, \mathrm{Fe}, \mathrm{K}, \mathrm{Mn}, \mathrm{P}$, and $\mathrm{Zn}$ ), micro- and trace elements ( Co, $\mathrm{Cr}, \mathrm{Cu}, \mathrm{Ni}, \mathrm{Se}$, and $\mathrm{V}$ ), and undesirable, potentially toxic elements (Al, As, Ba, Cd, Co, Cr, Hg, Ni, Pb, Sb, and $\mathrm{Sn}$ ) are monitored in this context [7]. This endeavor is performed using mainly the following analytical methods: flame atomic absorption spectrometry, electrothermal atomic absorption spectrometry, inductively coupled plasma optical emission spectrometry, and inductively coupled plasma mass spectrometry. These methods involve digestion of the samples, with certain losses, an uncertainty in methods applied to release of the elements from their natural matrix, and also instrument and operator errors [7]. There are also methods that use only finely grinded and homogenized samples, without further preparation, and are nondestructive and with high sensitivity: prompt-gamma neutron activation analysis and neutron activation analysis (NAA). NAA is a specific and accurate analysis technique, recently classified as a primary ratio method by metrology $[8,9]$. NAA is sensitive for trace elements ( $\mathrm{Cu}, \mathrm{Zn}$, As, Se, Rb, Sr, Sc, V, Cr, Co, Ni, Zr, As, Sb, $\mathrm{Ce}, \mathrm{Ba}, \mathrm{Hf}, \mathrm{Ta}$, and $\mathrm{W})$, for macroelements ( $\mathrm{Mg}, \mathrm{Ca}, \mathrm{Na}$, and $\mathrm{K}$ ), for other elements (as $\mathrm{Ti}, \mathrm{Al}, \mathrm{Fe}$, and $\mathrm{Mn}$ ), and also for rare earth elements and is particularly suitable for medicinal plants. The analysis of medicinal plants and tea by this method has a long history [10-13] but it is not very abundant in trials because of the high costs and low affordability. However, the results obtained by this method are valuable and rewarding [14-17]. Already in 1996, the World Health Organization (WHO) has recommended NAA as analytical method applicable for plant materials [18]. Furthermore, it was also used in a proficiency test for heavy metal content (undesirable substances) in vegetable feed to establish the reference values [19].

The aim of the present study is the NAA of the elements contained by seven herbs cultivated in medicinal crops, away from any source of pollution, originating from the central part of Romania. Furthermore, these herbs are representative medicinal plants, are accessible and widely used through different pharmaceuticals forms or voluntarily by the entire Romanian population, and are exported also in Europe. The results will be compared with those presented in the specialized literature and will be analyzed from point of view of their contributions to intake and toxicity of the metals for humans.

\section{Materials and Methods}

2.1. Sampling and Sample Preparation. The plant material has been selected as representative specific medicinal plant crop that is currently in production in an uncontaminated area, near to Orăştie, Romania: peppermint, plantain, chamomile, lavender, Echinacea, dill, and coriander. The seven species of plants were obtained from cultures of 2015. Species and plant parts used for analysis were leaves: Menthae folium from Mentha piperita L., and Plantaginis folium from Plantago lanceolata L.; flowers: Matricariae flos from Matricaria chamomilla L., and Lavandulae flos from Lavandula angustifolia Mill.; the aerial parts: Echinacea herba from Echinacea angustifolia DC.; fruits: Anethi fructus from Anethum graveolens L., and Coriandri fructus from Coriandrum sativum L. As standard reference material, the WEPAL (Wageningen Evaluating Programs for Analytical Laboratories) IPE sample 205 of Tobacco (leaf-mixture)/Nicotiana Solanaceae from Netherlands [20] was used.

The raw material, air-dried plants (about $100 \mathrm{~g}$ each), as they are used in production of a range of products, were finely crushed with a manual grinder with ceramic knives and with ceramic mortar and pestle. No metal tools were used to avoid the risk of contamination. The samples were strained through a plastic sieve with a meshed bottom ( $0.5 \mathrm{~mm}$ diameter). The average sample was obtained by quartering [23]. Given the assay sensitivity, the process of crushing and homogenization of samples has great importance for accurate and precise results. Samples were subjected to drying in an oven at $105^{\circ} \mathrm{C}$ to constant weight. The weight loss (water and some volatiles) was $9.11 \%, 7.16 \%, 7.27 \%, 7.93 \%, 9.31 \%, 7.29 \%$, and $7.28 \%$ for mint, plantain, chamomile, lavender, Echinacea, dill, and coriander, respectively. The samples obtained in this manner were delivered to the NAA. At the NAA laboratory a refining of the "drying" was carried on using independent samples ( $105^{\circ} \mathrm{C}, 4-6$ hours, dry until constant mass). The weight loss (\% volatiles) ranged between $0.24 \%$ and $0.79 \%$ for the analyzed plants and was $4.67 \%$ for the Tobacco leaf-mixture. Thus, the weights of the NAA samples were corrected with a mass factor of $1 /[1+(\%$ volatiles/100 $)]$. This value is considered as reference for the determined element contents, expressed as mg element/kg dry plant.

2.2. NAA. The neutron activation analysis was performed using the $10 \mathrm{MW}$ Budapest Research Reactor [9]. Short-term and long-term types of irradiation were undertaken targeting radioactive daughter nuclei, with short or long half-lives, as described [24].

Thus, for the short-term irradiation, samples of $3.1 \div$ $8.5 \mathrm{mg}$ were weighted, packed in Whatman 41 filter paper, pressed in pellet, and placed in cleaned polyethylene capsules and irradiated for 2 minutes. After irradiation, the sample pellets are repacked into inactive polyethylene and measured. A blank correction was performed for the Whatman 41 paper: the blank and the sample filter Whatman weights were always determined before sample preparation, and a subtraction was made for the "mass-factored" Whatman paper.

The 6-hour long-term irradiation was performed on samples of $44.3 \div 92.3 \mathrm{mg}$ sealed in high-purity quartz ampules, $6 \mathrm{~cm}$ long, $6 \mathrm{~mm}$ diameter, Suprasil@ AN, Heraeus. The Suprasil type quartz contains metallic trace impurities in concentrations $\leq 0.010 \mathrm{mg} / \mathrm{kg}$ (only for $\mathrm{Ca} \leq 0.015$ ), as stated in [25]. To remove surface contamination with some of the measured elements, the inner and outer surfaces of the ampules were etched in a mixture of hydrogen fluoride, acetic 
and nitric acid, and $\mathrm{H}_{2} \mathrm{O}_{2}$, washed with double distilled water, and dried (as described in [9]). The thermal equivalent flux parameters were $5.68 \cdot 10^{13}$ and $2.00 \cdot 10^{13} \mathrm{~cm}^{-2} \cdot \mathrm{s}^{-1}$; alpha (the deviation of the epithermal neutron flux distribution) 0.003 and $0.002 ; f$ (the ratio of the thermal to epithermal neutron flux) 37.9 and $51.2 ; 4.48 \cdot 10^{12}$ and $1.16 \cdot 10^{12}$ fast neutron flux $/ \mathrm{cm}^{2} \cdot \mathrm{s}$ for the short-term and long-term activation, respectively. In short-term irradiation the $\mathrm{Al}, \mathrm{Ca}$, $\mathrm{Cl}, \mathrm{Cu}, \mathrm{Mg}, \mathrm{Mn}, \mathrm{S}$, and $\mathrm{V}$ contents were evaluated, whereas As, $\mathrm{Au}, \mathrm{Ba}, \mathrm{Br}, \mathrm{Ce}, \mathrm{Co}, \mathrm{Cr}, \mathrm{Cs}, \mathrm{Eu}, \mathrm{Fe}, \mathrm{Ga}, \mathrm{K}, \mathrm{Na}, \mathrm{Rb}, \mathrm{Sb}, \mathrm{Sc}$, $\mathrm{Sm}, \mathrm{Sr}, \mathrm{Tb}, \mathrm{Th}, \mathrm{Yb}$, and $\mathrm{Zn}$ concentrations were investigated in long-term irradiation. The gamma-rays emitted from the samples were counted at 10 to $25 \mathrm{~cm}$ distances from an ntype coaxial HPGe with $36 \%$ relative efficiency [9] with 10 minutes of detection time, at 2-3 minutes after the shortterm irradiation, and in two stages (a) with 20 minutes of detection time at 3-4 days after the long-term irradiation and (b) with 6 hours of detection time at 25-30 days after the long-term irradiation. Spectra evaluation was performed (i.e., peak fitting) with the Hyperlab 2013 software [26], described in [27]. Concentration calculation was performed using the $k_{0}$-standardization method and the Kayzero for Windows software [28]. The given uncertainties are equal to 2 standard deviations including $3.5 \%$ systematical uncertainty (resulting mainly from the uncertainties in the measurement of terms from the definition of $k_{0}$, [29]) plus spectra evaluation uncertainty, that is, area determination uncertainty.

\section{Results}

To verify the performance statistics of the applied NAA method, a certified reference material was used: IPE sample 205 Tobacco (leaf-mixture), from the WEPAL reference materials. The chosen performance statistics parameter is the $E_{n}$ number in compliance with ISO 13528, 2015. The results are represented in Table 1. The means and the corresponding standard deviations for the reference material are extracted from the consensus table values (except for $\mathrm{Al}$, for which the consensus value is "so-called total" and consequently the indicative value is used) presented in the Certificate of Analysis-IPE sample 205, WEPAL [20].

Although [30] in the section "The Ashing of Organic samples" considers arsenic loss by volatilization important only in presence of $\mathrm{HCl}$ and thus [31] does not include arsenic in the list of oven-dried tested trace elements regarding possible losses, we discuss this problem. After a careful survey of the relevant literature, the findings are as follows: the common terrestrial plants uptake mainly water soluble (polar or ionic) species of arsenic, even if they are methylated and considered as "organic" [32]. In the plant, $\mathrm{As}(\mathrm{V})$ can be reduced to As(III), and a great part of these species are complexed with glutathione, phytochelatins, and proteins [33, 34]. The dissociation of these complexes produces also ionic or polar arsenic species [35]. Speciation studies (e.g., [36] refers also to one of our plants, plantain) demonstrate that even the noncomplexed arsenic species are very polar and nonvolatile or ionic compounds (e.g., dimethyl arsenic acid, monomethylarsonic acid, trimethyl arsine oxide, tetramethyl arsonium ion, and arsenobetaine). Thus, a significant arsenic
TABLE 1: IPE sample 205 Tobacco reference material [20] data (consensus values) and the NAA $E_{n}$ performance statistics parameter*

\begin{tabular}{|c|c|c|c|c|c|}
\hline $\begin{array}{l}\text { Element } \\
\left(\mathrm{mg} \cdot \mathrm{kg}^{-1}\right)\end{array}$ & $\begin{array}{c}\text { Reference } \\
\text { mean }\end{array}$ & Std. dev. & $\begin{array}{c}\text { Measured } \\
\text { mean }\end{array}$ & Uncertainty & $E_{n}$ \\
\hline As & 0.415 & 0.069 & 0.48 & 0.16 & 0.37 \\
\hline $\mathrm{Ba}$ & 23.0 & 3.16 & 32.94 & 9.34 & 1.01 \\
\hline $\mathrm{Br}$ & 99.0 & 9.39 & 102.8 & 3.7 & 0.38 \\
\hline $\mathrm{Cl}$ & 4600 & 326 & 4207 & 155 & 1.09 \\
\hline Co & 0.302 & 0.0471 & 0.34 & 0.03 & 0.68 \\
\hline $\mathrm{Cr}$ & 6.4 & 0.964 & 7.51 & 0.43 & 1.05 \\
\hline Cs & 0.0608 & 0.01314 & 0.05 & 0.01 & 0.65 \\
\hline $\mathrm{Cu}$ & 12.3 & 1.18 & 17.18 & 7.36 & 0.65 \\
\hline $\mathrm{Fe}$ & 330 & 37.7 & 366.5 & 19.7 & 0.86 \\
\hline $\mathrm{K}$ & 54900 & 3600 & 56150 & 2050 & 0.30 \\
\hline $\mathrm{Mg}$ & 4710 & 326 & 4930 & 194 & 0.58 \\
\hline $\mathrm{Mn}$ & 296 & 21.8 & 302.7 & 10.9 & 0.27 \\
\hline $\mathrm{Na}$ & 260 & 55.9 & 301.0 & 16.8 & 0.70 \\
\hline $\mathrm{Al}^{* *}$ & 388 & 180.3 & 566.5 & 19.8 & 0.98 \\
\hline $\mathrm{Ca}$ & 30700 & 1970 & 32056 & 1249 & 0.58 \\
\hline $\mathrm{Rb}$ & 26.5 & 2.92 & 28.28 & 1.71 & 0.53 \\
\hline $\mathrm{Sb}$ & 0.222 & 0.0507 & 0.24 & 0.02 & 0.33 \\
\hline $\mathrm{Sr}$ & 83.1 & 10.55 & 96.17 & 11.10 & 0.85 \\
\hline $\mathrm{Zn}$ & 187 & 14.0 & 201.6 & 7.8 & 0.91 \\
\hline $\mathrm{V}$ & 0.768 & 0.145 & 0.94 & 0.13 & 0.88 \\
\hline
\end{tabular}

${ }^{*}$ Std. dev.: standard deviation; measured mean: resulting from evaluation of the quantity of the element using several energy peaks from the gamma ray spectrum of the respective element (Kayzero for Windows, 2005) [21]; uncertainty: see Section 2.2; for the normalized error $E_{n}$, see ISO 13528, 2015 [22]. ${ }^{* *}$ Indicative value.

volatility and loss in the conditions of our sample preparation procedure are improbable. This is demonstrated also by the As $E_{n}$ value in our Table 1 .

Another potential problem might be the interference of an activated phosphorus isotope with that of aluminum, thus introducing errors (overestimation) in $\mathrm{Al}$ content determination. Following the rationale of Alfassi and Rietz [37], the contribution of the irradiated ${ }^{31} \mathrm{P}$ to the ${ }^{28} \mathrm{Al}$ signal can be determined. For a light water reactor (as the Budapest Research Reactor), using the mean of five values delivered by this reference $32.8 \mathrm{mg}$ of $\mathrm{P}$ in the sample gives the same ${ }^{28} \mathrm{Al}$ activity as $0.01 \mathrm{mg}$ of Al. Picking up the corresponding phosphorus content of our plants from [38-46] can calculate the mean P concentrations $(\mathrm{mg} / \mathrm{kg})$, as follows: coriander 4041, dill 1745, Echinacea 2810, lavender 2810, chamomile 3635 , mint 4046, plantain 4790, and Tobacco 4630 (from IPE 205) [20]. From these data, the following correction rates can be calculated for each of the plants: $4.07 \%, 0.34 \%, 1.80 \%$, $0.01 \%, 0.33 \%, 0.13 \%, 0.06 \%$, and $0.25 \%$, respectively. The values are in accordance with those obtained by [47] for plant standards. The numbers are less than the relative standard deviations for $\mathrm{Al}$ from Table 2. Thus, the perturbation caused by ${ }^{31} \mathrm{P}$ can be neglected. As a matter of fact, the $E_{n}$ value for 
TABLE 2: Concentration of the elements in representative medicinal plants as obtained by NAA: the values are means (mg. $\mathrm{kg}^{-1}$ ) and the corresponding relative standard deviations, RSD $(\%)^{*}$.

\begin{tabular}{|c|c|c|c|c|c|c|c|c|c|c|c|c|c|c|}
\hline \multirow{2}{*}{$\begin{array}{l}\text { Plant } \\
\mathrm{Al}\end{array}$} & \multicolumn{2}{|c|}{ Coriander } & \multicolumn{2}{|c|}{ Dill } & \multicolumn{2}{|c|}{ Echinacea } & \multicolumn{2}{|c|}{ Lavender } & \multicolumn{2}{|c|}{ Chamomile } & \multicolumn{2}{|c|}{ Mint } & \multicolumn{2}{|c|}{ Plantain } \\
\hline & 31.47 & 5.5 & 155.44 & 4.1 & 48.48 & 5.2 & 4996.71 & 3.6 & 334.88 & 3.9 & 975.55 & 3.7 & 2261.33 & 3.6 \\
\hline As & $<0.10$ & - & $<0.09$ & - & $<0.08$ & - & 1.16 & 10.9 & $<0.41$ & - & $<0.12$ & - & 0.42 & 39.6 \\
\hline $\mathrm{Au}$ & $<0.00$ & - & $<0.01$ & - & $<0.00$ & - & $<0.00$ & - & 0.04 & 11.9 & $<0.01$ & - & $<0.00$ & - \\
\hline $\mathrm{Ba}$ & $<6.9$ & - & 15.18 & 69.5 & $<7.74$ & - & 51.45 & 21.7 & $<8.16$ & - & 47.65 & 13.3 & 75.12 & 11.9 \\
\hline $\mathrm{Br}$ & 19.47 & 3.6 & 37.15 & 3.6 & 2.87 & 4.1 & 8.84 & 3.9 & 21.73 & 3.7 & 20.08 & 3.7 & 62.48 & 3.6 \\
\hline $\mathrm{Ca}$ & 6787.58 & 5.5 & 18830.62 & 4.5 & 7990.88 & 5.3 & 13113.55 & 4.4 & 9944.35 & 5.7 & 16295.94 & 4.7 & 15807.76 & 4.9 \\
\hline $\mathrm{Ce}$ & $<0.41$ & - & $<0.31$ & - & $<0.25$ & - & 6.07 & 5.7 & $<0.43$ & - & 1.81 & 10.3 & 4.97 & 5.4 \\
\hline $\mathrm{Cl}$ & 553.02 & 4.2 & 5747.27 & 3.7 & 3897.67 & 4 & 996.93 & 4 & 8210.21 & 3.8 & 3731.17 & 3.8 & 4080.99 & 3.8 \\
\hline Co & 0.04 & 31.7 & 0.16 & 6.9 & 0.13 & 11.6 & 1.3 & 4.4 & 0.1 & 13.6 & 1.82 & 4 & 0.8 & 4.3 \\
\hline $\mathrm{Cr}$ & $<0.35$ & - & 0.45 & 37.4 & 0.77 & 17.7 & 11.36 & 5.4 & 0.66 & 36 & 4.94 & 6.2 & 5.11 & 6.4 \\
\hline Cs & $<0.02$ & - & 0.03 & 30.6 & $<0.02$ & - & 0.73 & 5.8 & 0.07 & 19.8 & 0.11 & 13.4 & 0.27 & 7.8 \\
\hline $\mathrm{Cu}$ & 16.5 & 22.8 & $<24.81$ & - & $<15.35$ & - & $<31.62$ & - & 23.36 & 45.5 & 23.3 & 41.6 & 28.9 & 48 \\
\hline $\mathrm{Eu}$ & 0.08 & 5 & 0.59 & 3.7 & $<0.00$ & - & 0.11 & 5.6 & 0.04 & 10.9 & 0.03 & 10.6 & 0.09 & 5.3 \\
\hline $\mathrm{Fe}$ & 48.32 & 12.1 & 134.6 & 7.1 & 52.25 & 12.8 & 3315 & 3.8 & 239.1 & 8.1 & 498.2 & 9.3 & 1409 & 5.1 \\
\hline $\mathrm{Ga}$ & $<0.36$ & - & $<1.62$ & - & $<0.36$ & - & 1.66 & 40.9 & $<2.65$ & - & $<1.36$ & - & $<1.92$ & - \\
\hline K & 15840 & 3.7 & 18370 & 3.7 & 21740 & 3.6 & 26450 & 5.4 & 28330 & 3.7 & 18270 & 3.7 & 26670 & 3.7 \\
\hline $\mathrm{La}$ & $<0.02$ & - & 0.09 & 46.1 & 0.03 & 26.7 & 2.81 & 4 & 0.31 & 22.2 & 0.8 & 7.2 & 2.3 & 4.3 \\
\hline $\mathrm{Mg}$ & 3203.3 & 4.1 & 3842.72 & 4.5 & 1785.74 & 4.8 & 4001.01 & 4.6 & 3243.33 & 4.8 & 7298.65 & 4.3 & 3941.71 & 4.7 \\
\hline $\mathrm{Mn}$ & 29.41 & 3.9 & 38.85 & 3.9 & 5.66 & 5.5 & 90.53 & 3.7 & 117.25 & 3.7 & 113.43 & 3.7 & 86.56 & 3.8 \\
\hline $\mathrm{Na}$ & 62.29 & 5.1 & 1330 & 5.6 & 26.39 & 4.7 & 653.1 & 6.2 & 2875 & 5.8 & 1649 & 6.1 & 1853 & 5.6 \\
\hline $\mathrm{Rb}$ & 8.7 & 7.7 & 20.39 & 5.8 & 5.55 & 11.4 & 15.34 & 10.3 & 29.56 & 5.9 & 22.97 & 6 & 30.25 & 5.4 \\
\hline S & $<4050$ & - & $<6745$ & - & $<4258$ & - & $<7565$ & - & $<6883$ & - & 8866 & 39.5 & 9645 & 50.3 \\
\hline $\mathrm{Sb}$ & $<0.03$ & - & $<0.10$ & - & $<0.02$ & - & 0.15 & 18.9 & $<0.04$ & - & $<0.04$ & - & 0.06 & 41.3 \\
\hline Sc & 0.01 & 11.3 & 0.03 & 4.9 & 0.01 & 9.2 & 1.22 & 3.7 & 0.07 & 4.5 & 0.17 & 4 & 0.57 & 3.7 \\
\hline $\mathrm{Sm}$ & $<0.01$ & - & $<0.01$ & - & $<0.01$ & - & 0.52 & 4.6 & 0.04 & 33.4 & 0.13 & 8.6 & 0.41 & 4.5 \\
\hline $\mathrm{Sr}$ & 34.28 & 19.6 & 174.9 & 6 & 31.25 & 18.5 & 39.7 & 34 & 26.65 & 34.3 & 88.61 & 10.9 & 73.57 & 14.3 \\
\hline $\mathrm{Tb}$ & $<0.01$ & - & $<0.01$ & - & $<0.01$ & - & 0.08 & 15.2 & $<0.01$ & - & $<0.01$ & - & 0.05 & 12.6 \\
\hline Th & $<0.03$ & - & $<0.03$ & - & $<0.02$ & - & 0.96 & 5.4 & 0.07 & 29.6 & 0.26 & 8.1 & 0.67 & 5.1 \\
\hline V & $<0.08$ & - & 0.23 & 47.3 & $<0.07$ & - & 7.73 & 5.1 & 0.61 & 28.6 & 1.24 & 14.4 & 3.47 & 8.3 \\
\hline $\mathrm{Yb}$ & $<0.07$ & - & $<0.05$ & - & $<0.04$ & - & 0.25 & 13.6 & $<0.07$ & - & $<0.04$ & - & 0.18 & 12.9 \\
\hline $\mathrm{Zn}$ & 55.31 & 4.2 & 32.21 & 4.6 & 8.81 & 8.1 & 39.32 & 5.4 & 38.73 & 5 & 39.97 & 4.7 & 38.45 & 4.5 \\
\hline
\end{tabular}

* Mean: resulting from evaluation of the quantity of the element using several energy peaks from the gamma ray spectrum of the respective element (Kayzero [21]); RSD\% calculated from uncertainty: see Section $2.2 ;<$ under the limit of detection (specified as a value).

Al from Table 1 passed on the edge the ISO 13528, 2015 [22] test (see the Discussion).

The NAA results for the seven analyzed plants are presented in Table 2.

Although not all the elements present in Table 2 are monitored in Table 1, with a correctly implemented Kayzero assisted NAA is possible the reliable determination of the concentrations also for these elements [48]. As can be seen from $[9,49]$ at the Budapest Research Reactor the $k_{0}$ procedure was successfully implemented and validated. The statistical validation from Table 1 also assures that the results for these elements in Table 2 must present good accuracy levels. An older and a newer reference exemplifies similar situations from the literature $[50,51]$.

\section{Discussion}

The absolute values of the normalized error $E_{n}$ from Table 1 are smaller than 1, except for three elements for which they are very close to this value. With the critical value of $E_{n}$ being 1 (ISO 13528, [22]), the NAA values passed or very nearly passed the test of performance statistics. Thus, the method can be used for determination of the element concentrations in the investigated plant samples.

Among the essential metallic macroelements [52], potassium is present in the largest quantity in the analyzed samples. For this element, comparable results were obtained for chamomile, mint, and coriander (air-dried plant material collected from "local bazaar") by [43] using ICP-OES 


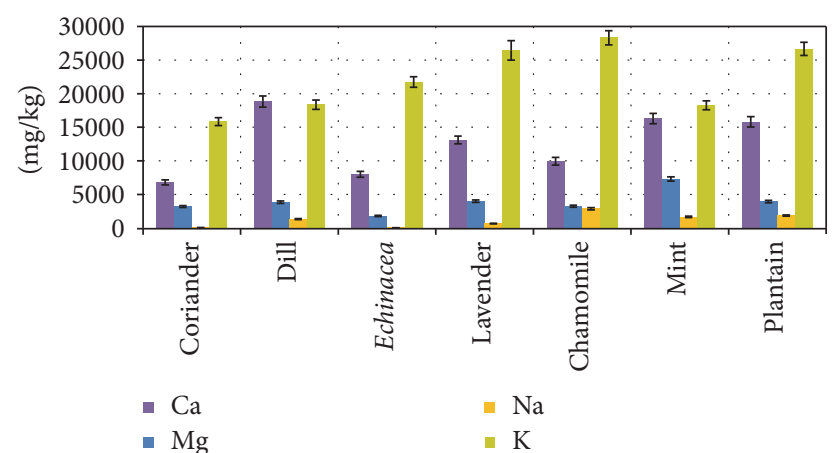

FIGURE 1: Selected macroelement ( $\mathrm{K}, \mathrm{Ca}, \mathrm{Mg}$, and $\mathrm{Na}$ ) content in the plant samples.

(Inductively Coupled Plasma Optical Emission Spectroscopy). Figure 1 presents the concentration $\mathrm{K}$ for the seven plant samples determined by NAA, together with other three macronutrients: $\mathrm{Ca}, \mathrm{Mg}$, and $\mathrm{Na}$.

Inspecting Figure 1, one can notice that for calcium and magnesium there is a visual similarity of the content ratio of these two elements in the plant samples. A similar behavior is reproduced for chamomile and mint in [43] and for Echinacea and mint in [39]. On the other hand, the $\mathrm{K} / \mathrm{Na}$ ratio was used to characterize the diuretic activity of several medicinal plants. The value obtained for chamomile $(615: 1)$ by [53] is very different from that obtained using the data from Table 2 $(\approx 10: 1)$, but $[43]$ confirms this last ratio.

Hereinafter the quantity of element retrieved in teas will be calculated using the percent transferred into the infusions/decoctions specified in the literature concerning the analyzed plant, taking into account the quantity of powdered tea plant used, if it is dried or not, and the concentrations from Table 2.

The amounts of $\mathrm{K}, \mathrm{Ca}$, and $\mathrm{Mg}$ transferred into teas from plant samples reported by [46] were between $51.6 \div$ $59.2 \%, 15.8 \div 35.7 \%$, and $18.1 \div 26.5 \%$ for coriander, mint, and chamomile, respectively. Using these values and taking into account for the three plants the concentrations from Table 2, $50 \mathrm{ml}$ tea prepared from $2.5 \mathrm{~g}$ of powdered plant (as was prepared in [46]) will contain between $20.8 \div 38.8 \mathrm{mg}$ of $\mathrm{K}, 3.5 \div 13.2 \mathrm{mg}$ of $\mathrm{Ca}$, and $1.3 \div 3.3 \mathrm{mg}$ of $\mathrm{Mg}$ intake. These amounts are far below the daily normative requirements and the recommendations provided by [52] for the three essential macronutrients but can represent a useful contribution to the food provided intake.

Figure 2 presents diagrams of selected trace and ultratrace [52] element concentrations for the analyzed medicinal plants. The first diagram (Figure 2(a)) contains toxic or potentially toxic elements and the second (Figure 2(b)) contains other elements. For comparison reasons and better clarity, the same elements are represented in two scales, a higher one and a lower one (see the figure's caption).

Being that any element may be toxic function of the intake quantity [52], the arsenic content of the analyzed plants is very low or under the limit of detection, as opposed to the results of $[43,54]$, on samples whose origin (spontaneous flora or cultivated) cannot be very clearly established. Furthermore, as stated by [54], for example, chamomile retains $32 \div 35 \%$ (mint only $12 \div 16 \%$ ) of the arsenic content of the infused plant. The WHO provisional Tolerable Daily Intake (TDI) value of $0.0021 \mathrm{mg} / \mathrm{kg}$ body weight/day was withdrawn [55] and no new level was established. In the USA [56] the TDI is $0.0003 \mathrm{mg} / \mathrm{kg}$ body weight/day $(0.021 \mathrm{mg} /$ day for an adult of $70 \mathrm{~kg}$ ). The highest arsenic concentration in Table 2 is retrieved for lavender, and with an infusion transfer of $35 \%$ a cup of tea using $2.5 \mathrm{~g}$ plant material contains $0.001 \mathrm{mg}$ As, far below the accepted daily level for a person.

"Toxic elements" chromium, vanadium, and cobalt are clearly present, but not in high amounts, in the lower concentration range of Figure 2(a).

The chromium level in the analyzed plants (under $1 \mathrm{mg} / \mathrm{kg}$, except mint, plantain, and lavender) in other papers is either approximately the same for lavender $[42,57]$ and for mint $[43,46]$ or greater for coriander, chamomile, and dill $[42,43,45,58]$. These papers state $\mathrm{Cr}$ recoveries, depending on the preparation method used, in the infusions of 3.6 to $10.9 \%$ (coriander, mint, and chamomile, $2.5 \mathrm{~g}$ plant in $50 \mathrm{ml}$ water, [46]) or 59 to $80 \%$ (chamomile, $2 \mathrm{~g}$ dry plant in $100 \mathrm{ml}$ boiling or hot water, 5 minutes, [58]). From the data of [59], the calculated chromium transfer in boiling water ( $1 \mathrm{~g}$ of plant powder in $200 \mathrm{ml}$ water) for mint is $23.5 \%$ and for chamomile $17.6 \%$. Paper [57] claims that the lavender chromium is very aqueous soluble in hot water (during the distillation for lavender oil preparation). Even using the worst case of infusion release $(80 \%)$, from $2.5 \mathrm{~g}$ of raw lavender sample from Table 2 (no percentage data for the infusion), $0.021 \mathrm{mg} \mathrm{Cr}$ is transferred in a cup of tea; the quantity is much smaller than the TDI of $0.245 \mathrm{mg}$, and the daily intake from mixed diet is only $0.061 \div 0.084 \mathrm{mg}$, all the quantities being calculated for an adult [52].

Other sources indicate the same vanadium concentrations as in Table 2 for mint and chamomile [43], somewhat smaller for lavender and greater for coriander and dill [42]. For vanadium in the USA, the Tolerable Upper Intake Level (equivalent with the TDI) is $1.8 \mathrm{mg}$ /day for an adult [60]; [52] indicates $7 \mathrm{mg} /$ day $(0.1 \mathrm{mg} / \mathrm{kg}$ body weight). Paper [61] stated that a tea produced from one bag (1.85 g) of peppermint leaves $\left(50 \mathrm{ml}\right.$ water at $95^{\circ} \mathrm{C}$, for 15 minutes) contains $22.5 \%$ of the vanadium from the raw material. The infusion $\mathrm{V}$ release compiled by [7] is $1.4 \div 40.5 \%$. Using the last value and the lavender $\mathrm{V}$ concentration from Table 2 a cup of tea prepared from $2.5 \mathrm{~g}$ raw plant powder contains $0.007 \mathrm{mg}$ of vanadium.

Only mint samples revealed lower concentrations of cobalt than those from Table 2; coriander and chamomile contain higher Co levels (data from $[43,46]$ ). The infusion transferred Co is $26.7,68.3$, and $15.3 \%$ for coriander, mint, and chamomile, respectively [46]. A mint tea prepared from leaves containing $1.82 \mathrm{mg} / \mathrm{kg}$ Co (Table 2) in the conditions mentioned by [46] will contain $0.003 \mathrm{mg}$ cobalt. There is no official WHO established TDI value for cobalt intake [62], but $0.0014 \mathrm{mg} / \mathrm{kg}$ body weight $(\approx 0.1 \mathrm{mg} /$ day $)$ was proposed by [63].

As a consequence of the last three paragraphs the chromium, vanadium, and cobalt concentration values from Table 2 are not alarming. 


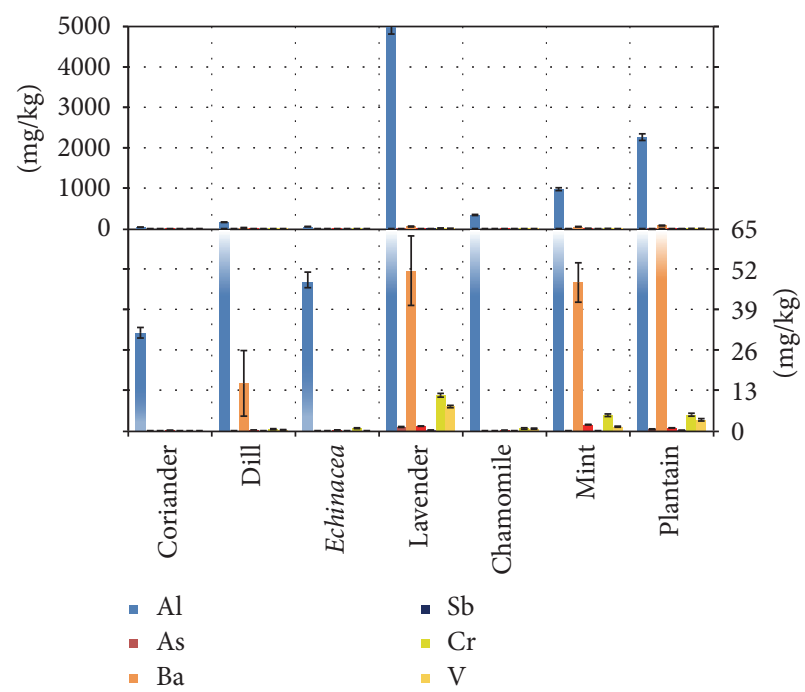

(a)

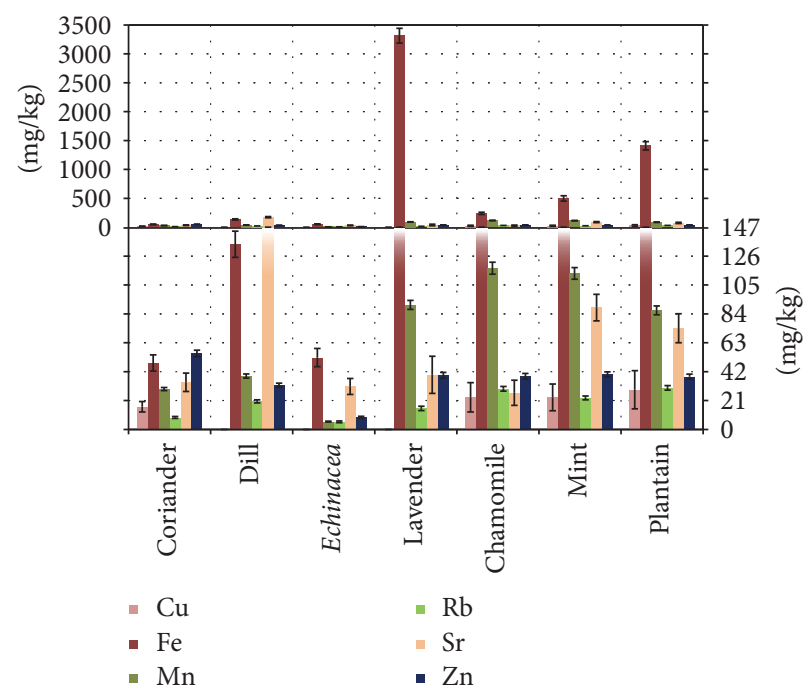

(b)

Figure 2: Diagrams of trace and ultra-trace (micronutrient) element concentrations for the seven plant samples; each element is represented in two concentration ranges: a higher one (left vertical axis and upper part of the chart) and a lower one (right vertical axis and lower part of the chart; the gradient fill suggests that the values are higher than the upper limit of this range): (a) elements with toxic or potentially toxic effects and (b) other elements.

The metals with the most significant concentrations in Figure 2(a) are barium and aluminum.

Comparatively with the values from Table 2, the barium concentration levels reported in other papers are slightly higher (coriander, [43]), higher (coriander, [42]; chamomile, [64]), much higher (mint and chamomile, [65]) of the same order of magnitude (mint, [43, 45, 61]; lavender, [42]), or smaller (in plantain flowers, [66]). Only $18.2 \div 18.5 \%$ of $\mathrm{Ba}$ is extractable by infusion from the mint leaves (1 tea bag, $100 \mathrm{ml}$ boiling water, 5 minutes, [45]) and 20\% from chamomile flowers ( $0.5 \mathrm{~g}$ tea, $25 \mathrm{ml}$ water, 30 minutes, [64]). The richest Ba content from the plants in Figure 2(a) presents plantain. Taking into account the maximum percentage value from the range mentioned by Pohl et al. (2016) [7] for Ba transfer, the extraction of a bag of 2.5 plantain ends with $0.099 \mathrm{mg}$ $\mathrm{Ba}$ in the infusion. The assessed TDI of barium is $0.2 \mathrm{mg} / \mathrm{kg}$ body weight, that is, $14 \mathrm{mg}$ daily intake for an adult [67]. Consequently, even in the extreme conditions used above, the concentrations from Table 2 are acceptable.

Seemingly the Al content from Figure 2(a) is of some concern, but different medicinal plants contain much more aluminum: the Camellia sinensis tea leaves over $30,000 \mathrm{mg} / \mathrm{kg}$ [68], some Moroccan plants $12265 \div 79152 \mathrm{mg} / \mathrm{kg}$ [69], green teas up to $13000 \mathrm{mg} / \mathrm{kg}$, and black teas up to $27000 \mathrm{mg} / \mathrm{kg}$ [70]. For herbal teas, the aluminum content is generally lower than for black and green teas [71]. In the literature for the plants from Table 2, similar Al concentration values were recorded by $[43,46]$ (mint) and by $[43,64]$ (chamomile). At the same time, lower values were measured for mint by $[44,45,59]$, for chamomile by $[44,46,59]$, and for lavender and for dill by [42]. But the aluminum concentration is almost twice of that from Table 2 for plantain flowers in [66] and 14 times and 46 times greater for coriander in [42] and [46], respectively. The aluminum content in infusions depends on the duration of the extraction process: for eight different Camellia sinensis tea samples produced in four countries, the recovery was between $19.5 \div 49.7 \%$ for 2 minutes, $29.4 \div$ $60.2 \%$ for 5 minutes, and $33.2 \div 63.3 \%$ for 10 minutes [72]. Szymczycha-Madeja et al. [70] in a survey article register a range of $2.6 \div 42.5 \%$ of $\mathrm{Al}$ recovery for green teas and $2.6 \div$ $63.3 \%$ for black teas. For herbal teas, [71] indicates Al recovery values within $1.37 \div 3.61 \%$. Likewise, for the herbal plants from Table 2, the aluminum extracted through infusion or decoction must cover a narrower range (the preparation conditions were already described for almost all references mentioned hereinafter). Indeed, for chamomile the values are $0.43 \%$ [64], $4.18 \%$ [46], and $15.1 \%$ [59]; for mint $0.16 \%$ [46], $1.66 \div 2.1 \%$ [70], and $17.6 \%$ [59]; for coriander $0.19 \%$ [46]. The plant rising apparently concerns inspecting Figure 2(a) is lavender. A cup of tea prepared from $2.5 \mathrm{~g}$ of lavender implying the value of $63.3 \%$ recovery (see above) is about $7.2 \mathrm{mg}$ $\mathrm{Al}$ or using the maximum recovery value obtained among the herbal plants, about $2 \mathrm{mg} \mathrm{Al}$. The first condition imposed here is severe (the highest percentage from the literature, 10 minutes of extraction time, very high leachability of $\mathrm{Al}$ from the tea matrix, Tetley tea, already in the first 2 minutes 44.9\%); thus the real values are certainly smaller than $7.2 \mathrm{mg}$. In the chapter of Anke [52], the TDI for $\mathrm{Al}$ is $1 \mathrm{mg} / \mathrm{kg}$ body weight, $70 \mathrm{mg}$ for an adult/day, or $20 \mathrm{mg} /$ day if the assessed provisional tolerable weekly intake of $2 \mathrm{mg} / \mathrm{kg}$ body weight from [73] is used. The daily $\mathrm{Al}$ intake of adults with mixed diet reported by [52] is $5.4 \mathrm{mg}$ for women and $5.8 \mathrm{mg}$ for men. So, as stated in [74], some teas should be consumed with caution (e.g., letting tea steep no longer than 3 minutes), to not exceed the TDI threshold level. It can be mentioned also that an in vitro method suggests that only $4.8 \%$ of the 
$\mathrm{Al}$ from a tea infusion is potentially available for absorption [75], and rat in vivo experiments establish that only $0.37 \%$ is orally bioavailable [76]. Also, [77] suggests based on ingestion in healthy volunteers that " $\mathrm{Al}$ ingested from short-term tea drinking does not contribute significantly to the total body burden of this metal." The facts described here suggest on the one hand that the $\mathrm{Al}$ concentrations from Table 2 are not unusual and on the other hand that the quantities recovered in infusions in the conditions of usual daily tea consumption are below the TDI value.

Besides the papers mentioned at the analysis of Figure 2(a), for comparison reasons concerning the metals represented in Figure 2(b), the following references were used: [38, 78-81].

Generally, the iron content of the plants from Table 2 in other references is higher for Echinacea and dill, smaller for lavender, approximately the same or smaller for mint and plantain, and the same, smaller, or higher for coriander and chamomile. In the case of lavender, the highest value from the references is 2.7 times smaller than that from Table 2. The Fe recovery by infusion for mint is $0.26 \div 6.84 \%$, for chamomile $3 \div 14.61 \%$, for Echinacea $6.43 \%$, and for coriander $0.41 \%$. The values are small or moderate; consequently, the concentration levels obtained for these plants and presented in Table 2 are not troublesome, especially as [70] classified $\mathrm{Fe}$ among the poorly extractable elements (below 20\%). If the highest percentage of release mentioned above is used to estimate the Fe content of a cup of tea prepared from $2.5 \mathrm{~g}$ lavender, the result, $1.1 \mathrm{mg}$, is well below the TDI for an adult, $0.7 \mathrm{mg} / \mathrm{kg}$ body weight, that is, $49 \mathrm{mg}$ for an adult [52].

In Table 2, the highest concentrations for $\mathrm{Cu}$ and $\mathrm{Mn}$ are retrieved for plantain and for chamomile, respectively. Other sources indicate for plantain slightly smaller $\mathrm{Cu}$ concentration levels and for chamomile similar, smaller, or higher $\mathrm{Mn}$ concentrations. The estimated $\mathrm{Cu}$ retrieval in infusions for mint, chamomile, and coriander ranges between 21.3 and $86.63 \%$. This led to a maximum $0.038 \mathrm{mg}$ of copper (chamomile, 69.58\% retrieval, $2.5 \mathrm{~g}$ tea flowers, [46]) in a cup of tea, the TDI value being $0.175 \mathrm{mg} / \mathrm{kg}$ body weight, or $12.25 \mathrm{mg}$ for an adult [52]. The literature mentions maximum percentage for manganese retrieved in infusion being $97.5 \%$ for chamomile and $40.2 \%$ for mint, meaning that using $2.5 \mathrm{~g}$ of the corresponding plant samples from Table 2 a cup of tea will contain about $0.28 \mathrm{mg}$ and $0.11 \mathrm{mg} \mathrm{Mn}$, respectively. The TDI value for an adult is $4.2 \mathrm{mg} /$ day, that is, $0.06 \mathrm{mg} / \mathrm{kg}$ body weight [82].

The normative requirement of zinc for women and men is up to $6 \div 8 \mathrm{mg} / \mathrm{day}$, and the TDI is $0.600 \mathrm{mg} /$ day body weight [52]. Similar $\mathrm{Zn}$ concentrations with those from Table 2 are retrieved in the literature for lavender and mint. Coriander exhibits smaller $\mathrm{Zn}$ levels, and higher or smaller values are mentioned for Echinacea, dill, and chamomile. The infusion concentrations of $\mathrm{Zn}$ represent 21 to $73 \%$ of the metal content of the plant powder used. This means implying the concentration values from Table $2(\approx 40 \mathrm{mg} / \mathrm{kg})$, up to $0.07 \mathrm{mg} \mathrm{Zn}$ per cup of tea.

The Sr concentrations from Table 2 are the same or smaller in the monitored papers, but the element is mentioned between the poorly extractable ones $(<20 \%)$ by [44].

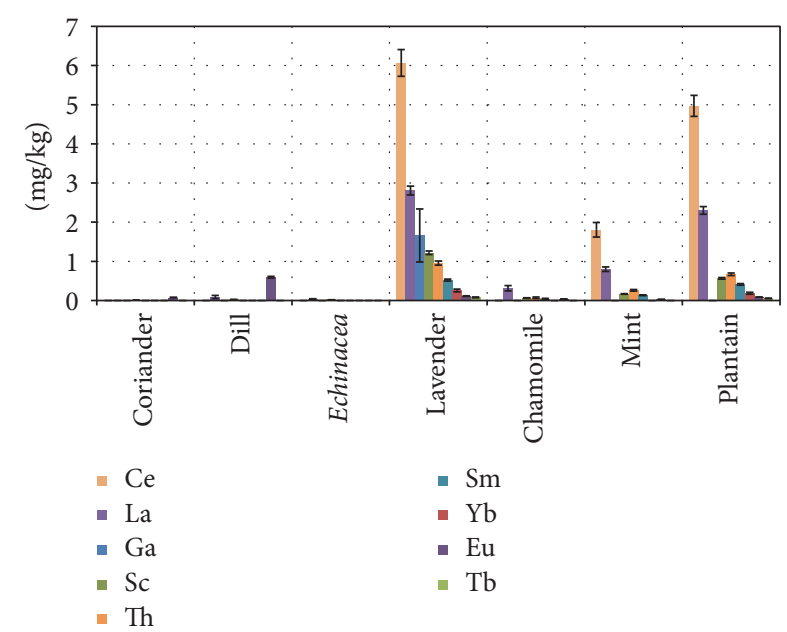

Figure 3: Concentrations of the rare earths in the plant samples.

Considering 20\% retrieval for dill (the highest Sr content in Table 2), one can consider $0.08 \mathrm{mg}$ intake for $2.5 \mathrm{~g}$ of plant infusion, which is much below the TDI of $9.1 \mathrm{mg} /$ day for an adult [83].

Although rubidium seems to be most important for human health [52], very few data are mentioned in the literature for the plants from Table 2. The concentrations for chamomile are similar and for mint smaller. Concerning the total metal in the tea samples (Lipton Yellow Label, 50 tea bags) $85 \%$ is soluble by infusion [84]. Using the $\mathrm{Rb}$ content for plantain (Table 2) and the $85 \%$ retrieval, $2.5 \mathrm{~g}$ of plant, a cup of tea will contain about $0.06 \mathrm{mg}$ of rubidium. The $\mathrm{Rb}$ TDI is $2 \mathrm{mg} /$ body weight [52].

Consequently, the metal concentrations presented in Figure 2(b) do not cause problems in what regards the safety for consumption of teas prepared from the corresponding plants.

Analyzing Figure 2 as a whole, a parallelism between the concentrations of $\mathrm{Al}$ and $\mathrm{Fe}$ is found. That is not surprising because when the metal concentrations of seven medicinal herbs (among these peppermint and chamomile), each one from two producers, were analyzed, a higher than 0.8 positive correlation coefficient was calculated between the concentrations of aluminum and iron [44]. Also, [85] discovers a positive correlation between $\mathrm{Al}$ and $\mathrm{Fe}(r=0.74)$ for twelve commercial bagged black teas. The metal content for these elements in the plant samples from Table 2 (see also Figure 2) is in order lavender $>$ plantain $>$ mint $>$ chamomile. This is in line with the literature, which has recorded several strategies of phytoremediation of contaminated soils using lavender crop [86], peppermint [87], plantain [88], and even chamomile [89]. It can be mentioned that the metal accumulation in lavender inflorescences does not contaminate the lavender oil produced from these [90].

Rare earth level determinations in medicinal plants are rather scarce in the literature. The concentrations of rare earths in the samples from Table 2 confirm the accumulation capacity of some of the plants and also the concentration order discussed above. Figure 3 demonstrates clearly this fact. 
The accumulation is more pronounced for the aerial part of the plants, than for the roots [91]. Paper [92] reports concentration values for cerium and lanthanum smaller for chamomile leaves than those from Table 2 and Figure 3 (here for flowers) and similar for Mentha piperita shoots (leaves in this paper), but much higher for Mentha pulegium leaves. In the case of Plantago major, a similar species with Plantago lanceolate, the reference indicates similar concentration for $\mathrm{Ce}$ and greater concentration for La. The same paper records for the infusion/decoction of the mentioned plants transfer factors lower than $10 \%$. A cup of tea prepared from $2.5 \mathrm{~g}$ lavender (highest concentration in Table 2) will contain using a transfer of $10 \% 0.0014 \mathrm{mg}$ Ce or $0.0006 \mathrm{mg} \mathrm{La}$. The acceptable daily intake is $0.6 \mathrm{mg} / \mathrm{kg}$ body weight for rare earth oxides in [93] that means $0.5 \mathrm{mg} / \mathrm{kg}$ body weight for the metals ( $42 \mathrm{mg}$ per person of $70 \mathrm{~kg}$ /day oxide or $35 \mathrm{mg}$ metal). These circumstances suggest that the rare earths concentrations from Table 2 are normal and acceptable from toxicological point of view.

Lanthanides reveal a 0.01 ratio of the water dissolved element and the concentration in soil [94]. Soluble fractions of these elements from soil are absorbed by plants. The abundance of cerium, as average concentration in the soil, is $60 \mathrm{mg} / \mathrm{kg}$ and of lanthanum $30 \mathrm{mg} / \mathrm{kg}$ [95]. Lavender blossoms concentrate the largest quantities of rare earth elements. The concentration ratio between rare earth elements present in this plant (Table 2) and their concentration in soil is 0.1 , equal for each of the analyzed elements (Ce, La, Sm, Eu, $\mathrm{Tb}, \mathrm{Th}$, and $\mathrm{Yb}$ ). This constant ratio demonstrates a specific behavior, by the absence of the preference for some of the elements, and is 10 times higher than the solubility ratio mentioned above. This fact further evidences the bioaccumulation capacity of lavender.

\section{Conclusions}

A comparison with the element content of the plants originated from spontaneous flora and the plants analyzed here is difficult to perform, because only few papers declare clearly the nature of sample provenance. Only [59] states that the analyzed plants originate from the spontaneous flora. One can only surmise that at least part of the analyzed samples in $[42,43,46,66]$ were harvested from the spontaneous flora, because the plants were purchased from the "local bazar or market" or were "plants growing in Turkey."

The comparative survey of these references and Table 2 led to the following conclusions: (a) the magnesium and calcium content (elements with normal daily intake below the requirement) are higher in the present study for chamomile and mint and the same for lavender; (b) the Fe and $\mathrm{Zn}$ level (marginally deficient elements in the daily food intake) are approximately the same, except lavender, for which the Fe content is higher in Table 2; (c) the toxic or potentially toxic elements present generally greater concentrations in the plants from spontaneous flora: As (chamomile), Al (coriander and plantain), Ba (chamomile, coriander, and dill), and $\mathrm{Cr}$ (chamomile and dill). Exception is the Al from lavender which is at higher level in Table 2, owing probably to the properties of the soil of the region where the plants were cultivated. Thus, the strategy to cultivate the medicinal plants choosing unpolluted area is practical and efficient.

The ability of individual plants to concentrate preferentially certain elements or group of elements suggests the need of controlling the level of some contaminants (e.g., aluminum) in herbal supplements. The same phenomenon suggests labeling of the products with higher content of potential contaminants, drawing the attention to limit the steeping of tea samples for short time.

\section{Abbreviations \\ ICP-OES: Inductively Coupled Plasma Optical Emission Spectroscopy \\ NAA: Neutron activation analysis \\ TDI: Tolerable Daily Intake \\ WEPAL: Wageningen Evaluating Programs for Analytical Laboratories.}

\section{Conflicts of Interest}

The authors declare that there are no conflicts of interest regarding the publication of this paper.

\section{Acknowledgments}

Daniela Haidu would like to thank the team from NAA Department, Budapest Neutron Center, for their professional support. This project has received funding from the European Union's 7th Framework Programme for research, technological development, and demonstration under the NMI3-II Grant no. 283883. The authors are also thankful for the financial support of the MTA INFRA infrastructure development grants.

\section{References}

[1] N. Wiseman, "Designations of medicines," Evidence-Based Complementary and Alternative Medicine, vol. 1, no. 3, pp. 327329, 2004.

[2] K. Busia, Fundamentals of Herbal Medicine, History, Phytopharmacology and Phytotherapeutics, vol. 1, Xlibris LLC, Bloomington, IN, USA, 2016.

[3] H. R. Alzahrani, H. Kumakli, E. Ampiah et al., "Determination of macro, essential trace elements, toxic heavy metal concentrations, crude oil extracts and ash composition from Saudi Arabian fruits and vegetables having medicinal values," Arabian Journal of Chemistry, In Press.

[4] T. Efferth and H. J. Greten, "Quality control for medicinal plants," Medicinal \& Aromatic Plants, vol. 1, article e131, 2012.

[5] N. Aksuner, E. Henden, Z. Aker, E. Engin, and S. Satik, "Determination of essential and non-essential elements in various tea leaves and tea infusions consumed in Turkey," Food Additives and Contaminants: Part B Surveillance, vol. 5, no. 2, pp. 126-132, 2012.

[6] N. Lydakis-Simantiris, M. Fabian, and M. Skoula, "Cultivation of medicinal and aromatic plants in heavy metal contaminated soils," Global Nest Journal, vol. 18, no. 630, pp. 630-642, 2016, http://journal.gnest.org/sites/default/files/Submissions/gnest_ 01829/gnest_01829_published.pdf. 
[7] P. Pohl, A. Dzimitrowicz, D. Jedryczko, A. Szymczycha-Madeja, M. Welna, and P. Jamroz, "The determination of elements in herbal teas and medicinal plant formulations and their tisanes," Journal of Pharmaceutical and Biomedical Analysis, vol. 130, pp. 326-335, 2015.

[8] R. R. Greenberg, P. Bode, and E. A. De Nadai Fernandes, "Neutron activation analysis: a primary method of measurement," Spectrochimica Acta Part B: Atomic Spectroscopy, vol. 66, no. 3-4, pp. 193-241, 2011.

[9] L. Szentmiklósi, D. Párkányi, and I. Sziklai-László, "Upgrade of the Budapest neutron activation analysis laboratory," Journal of Radioanalytical and Nuclear Chemistry, vol. 309, no. 1, pp. 91-99, 2016.

[10] T. Takeo and M. Shibuya, "Determination of trace elements in tea plant by neutron activation analysis," Radioisotopes, vol. 20, pp. 25-28, 1971, https://www.jstage.jst.go.jp/article/radioisotopes1952/20/1/20_1_25/_pdf.

[11] M. Kasrai, M. J. Shoushtarian, and M. H. Bozorgzadeh, "Determination of trace elements in tea leaves by neutron activation analysis," Journal of Radioanalytical Chemistry, vol. 41, no. 1-2, pp. 73-79, 1977.

[12] Y. Serfor-Armah, E. H. K. Akaho, B. J. B. Nyarko, A. W. K. Kyere, and K. Oppon-Boachie, "Application of instrumental neutron activation analysis to plant medicines in Ghana: a review," Journal of Radioanalytical and Nuclear Chemistry, vol. 257, no. 1, pp. 125-128, 2003.

[13] M. K. Mahani and M. G. Maragheh, "Simultaneous determination of sodium, potassium, manganese and bromine in tea by standard addition neutron activation analysis," Food Analytical Methods, vol. 4, no. 1, pp. 73-76, 2011.

[14] R. A. Lagad, D. Alamelu, R. Acharya, and S. K. Aggarwal, "Instrumental neutron activation analysis for multi-elemental determination in Indian tea samples," Journal of Radioanalytical and Nuclear Chemistry, vol. 288, no. 2, pp. 613-620, 2011.

[15] H. S. Moreira, M. B. A. Vasconcellos, E. R. Alves, F. M. Santos, and M. Saiki, "Elemental composition of herbal medicines sold over-the-counter in São Paulo city, Brazil," Journal of Radioanalytical and Nuclear Chemistry, vol. 290, no. 3, pp. 615621, 2011.

[16] H. Zhang, B. Ni, W. Tian et al., "Study on essential and toxic elements intake from drinking of Chinese tea," Journal of Radioanalytical and Nuclear Chemistry, vol. 287, no. 3, pp. 887892, 2011.

[17] M. A. Islam and M. Ebihara, "Elemental characterization of Japanese green tea leaves and tea infusion residue by neutroninduced prompt and delayed gamma-ray analysis," Arabian Journal of Chemistry, vol. 10, supplement 1, pp. S677-S682, 2012.

[18] World Health Organization, Trace Elements in Human Nutrition and Health, World Health Organization, Geneva, Switzerland, 1996, (accessed December 2016), http://www.who.int/ nutrition/publications/micronutrients/9241561734/en/.

[19] F. Cordeiro, P. Robouch, J. Charoud-Got et al., "Determination of total $\mathrm{As}, \mathrm{Cd}, \mathrm{Pb}$ and $\mathrm{Hg}$ in vegetable feed," IMEP-119 Proficiency Test Report, European Commission, Brussels, Belgium, 2014, (accessed November 2016), http://publications.jrc .ec.europa.eu/repository/bitstream/111111111/33790/1/imep-119_ final_report.pdf.

[20] "Certificate of Analysis-IPE sample 205, Tobacco (leafmixture, Nicotiana solanaceae," International Plant-analytical Exchange Programme, Wageningen Evaluating Programmes for Analytical Laboratories (WEPAL), Wageningen University, Netherland, (accessed july 2016), http://www.wepal.nl/ website/products/RefMatIPE.htm.

[21] Kayzero for Windows, User's Manual, DSM Research, Geleen, Netherland, 2005, (accessed March 2017), http://www.kayzero .com/KfW\%20Manual\%20V1.pdf.

[22] ISO 13528, "Statistical methods for use in proficiency testing by interlaboratory comparison," Published in Switzerland, (accessed July 2016), http://www.iso.org/iso/catalogue_detail .htm? csnumber $=56125$.

[23] WHO, Quality Control Methods for Herbal Materials, World Health Organization, Geneva, Switzerland, 2011, (accessed January 2016), http://apps.who.int/medicinedocs/documents/ h1791e/h1791e.pdf.

[24] K. Gméling, A. Simonits, I. Sziklai László, and D. Párkányi, "Comparative PGAA and NAA results of geological samples and standards," Journal of Radioanalytical and Nuclear Chemistry, vol. 300, no. 2, pp. 507-516, 2014.

[25] Heraeus, "Quartz Glass for Optics. Data and Properties," (accessed March 2017), https://www.heraeus.com/media/media/hqs/ doc_hqs/products_and_solutions_8/optics/Data_and_Properties_Optics_fused_silica_EN.pdf.

[26] HyperLab, Gamma Spectroscopy Software Installation Guide 1998-2013, HyperLabs Software, Budapest, Hungary, 2013.

[27] A. Simonits, J. Östör, S. Kálvin, and B. Fazekas, "HyperLab: a new concept in gamma-ray spectrum analysis," Journal of Radioanalytical and Nuclear Chemistry, vol. 257, no. 3, pp. 589595, 2003.

[28] F. De Corte, R. Van Sluijs, A. Simonits et al., "Installation and calibration of Kayzero-assisted NAA in three Central European countries via a Copernicus project," Applied Radiation and Isotopes, vol. 55, no. 3, pp. 347-354, 2001.

[29] F. De Corte, The $k^{0}$ standardization method: a move to the optimization of neutron activation analysis [Habilitation thesis], University of Gent, Ghent, Belgium, 1987.

[30] T. T. Gorsuch, "Dissolution of organic materials," in Accuracy in Trace Analysis: Sampling, Sample Handling, Analysis, P. D. LaFleur, Ed., vol. 422, pp. 491-508, National Bureau of Standards Special Publication, 1976, https://archive.org/details/ accuracyintracea4222lafl.

[31] G. V. Iyengar, K. Kasperek, and L. E. Feinendegen, "Retention of the metabolized trace elements in biological tissues following different drying procedures. I. Antimony, cobalt, iodine, mercury, selenium and zinc in rat tissues," Science of the Total Environment, The, vol. 10, no. 1, pp. 1-16, 1978.

[32] F. J. Zhao, J. F. Ma, A. A. Meharg, and S. P. McGrath, "Arsenic uptake and metabolism in plants," New Phytologist, vol. 181, no. 4, pp. 777-794, 2009.

[33] A. A. Meharg and J. Hartley-Whitaker, "Arsenic uptake and metabolism in arsenic resistant and nonresistant plant species," New Phytologist, vol. 154, no. 1, pp. 29-43, 2002.

[34] P. M. Finnegan and W. Chen, "Arsenic toxicity: the effects on plant metabolism," Frontiers in Physiology, vol. 3, article 182, 2012.

[35] A. Raab, A. A. Meharg, M. Jaspars, D. R. Genney, and J. Feldmann, "Arsenic-glutathione complexes-their stability in solution and during separation by different HPLC modes," Journal of Analytical Atomic Spectrometry, vol. 19, no. 1, pp. 183190, 2004.

[36] A. Geiszinger, W. Goessler, and W. Kosmus, "Organoarsenic compounds in plants and soil on top of an ore vein," Applied Organometallic Chemistry, vol. 16, no. 5, pp. 245-249, 2002. 
[37] Z. B. Alfassi and B. Rietz, "Determination of aluminium by instrumental neutron activation analysis in biological samples with special reference to NBS SRM 1577 Bovine Liver," The Analyst, vol. 119, no. 11, pp. 2407-2410, 1994.

[38] R. Chizzola, H. Michitsch, and U. S. Mitteregger, "Extractability of selected mineral and trace elements in infusions of chamomile," International Journal of Food Sciences and Nutrition, vol. 59, no. 6, pp. 451-456, 2008.

[39] R. N. Gallaher, K. Gallaher, A. J. Marshall, and A. C. Marshall, "Mineral analysis of ten types of commercially available tea," Journal of Food Composition and Analysis, vol. 19, pp. S53-S57, 2006.

[40] K. C. Harrington, A. Thatcher, and P. D. Kemp, "Mineral composition and nutritive value of some common pasture weeds," New Zealand Plant Protection, vol. 59, pp. 261-265, 2006, https://www.nzpps.org/journal/59/nzpp_592610.pdf.

[41] P. Konieczynski and M. Wesolowski, "Phytate, inorganic and total phosphorus and their relations to selected trace and major elements in herbal teas," Acta Poloniae Pharmaceutica Drug Research, vol. 71, pp. 85-93, 2014, http://www.ptfarm.pl/ pub/File/Acta_Poloniae/2014/1/085.pdf.

[42] M. Özcan, "Mineral contents of some plants used as condiments in Turkey," Food Chemistry, vol. 84, no. 3, pp. 437-440, 2004.

[43] M. Özcan, A. Ünver, T. Uçar, and D. Arslan, "Mineral content of some herbs and herbal teas by infusion and decoction," Food Chemistry, vol. 106, no. 3, pp. 1120-1127, 2008.

[44] K. Pytlakowska, A. Kita, P. Janoska, M. Połowniak, and V. Kozik, "Multi-element analysis of mineral and trace elements in medicinal herbs and their infusions," Food Chemistry, vol. 135, no. 2, pp. 494-501, 2012.

[45] A. Szymczycha-Madeja, M. Welna, and W. Zyrnicki, "Multielement analysis, bioavailability and fractionation of herbal tea products," Journal of the Brazilian Chemical Society, vol. 24, no. 5, pp. 777-787, 2013.

[46] M. Zengin, M. M. Özcan, Ü. Çetin, and S. Gezgin, "Mineral contents of some aromatic plants, their growth soils and infusions," Journal of the Science of Food and Agriculture, vol. 88, no. 4, pp. 581-589, 2008.

[47] Y. Yamamoto, Y. Katoh, and T. Sato, "Determination of aluminum in various biological materials using Instrumental Neutron Activation Analysis," Legal Medicine, vol. 11, no. 1, pp. S440-S442, 2009.

[48] R. Acharya, A. Nair, A. Reddy, and S. Manohar, "Validation of a neutron activation analysis method using k0-standardization," Applied Radiation and Isotopes, vol. 57, no. 3, pp. 391-398, 2002.

[49] F. De Corte, R. van Sluijs, A. Simonits et al., "The validation of Kayzero-assisted NAA in Budapest, Řež, and Ljubljana via the analysis of three BCR certified reference materials," Analytical and Bioanalytical Chemistry, vol. 370, no. 1, pp. 38-41, 2001.

[50] R. N. Acharya, P. P. Burte, A. G. C. Nair, A. V. R. Reddy, and S. B. Manohar, "Multielement analysis of natural ruby samples by neutron activation using the single comparator method," Journal of Radioanalytical and Nuclear Chemistry, vol. 220, no. 2, pp. 223-227, 1997.

[51] P. M. B. Salles, M. Â. D. B. C. Menezes, R. Jaćimović, and T. P. R. Campos, "Inorganic elements in sugar samples consumed in several countries," Journal of Radioanalytical and Nuclear Chemistry, vol. 308, no. 2, pp. 485-493, 2016.

[52] M. K. Anke, "Essential and toxic effects of macro, trace, and ultratrace elements in the nutrition of man," in Elements and Their Compounds in the Environment, E. Merian, M. Anke,
M. Ihnat, and M. Stoeppler, Eds., Wiley-VCH Verlag GmbH \& Co. KGaA, Weinheim, Germany, 2nd edition, 2004.

[53] K. Szentmihályi, Á. Kéry, M. Then, B. Lakatos, Z. Sándor, and P. Vinkler, "Potassium-sodium ratio for the characterization of medicinal plant extracts with diuretic activity," Phytotherapy Research, vol. 12, no. 3, pp. 163-166, 1998.

[54] S. Arpadjan, G. Çelik, S. Taşkesen, and Ş. Güçer, "Arsenic, cadmium and lead in medicinal herbs and their fractionation," Food and Chemical Toxicology, vol. 46, no. 8, pp. 2871-2875, 2008.

[55] WHO, "Exposure to arsenic: a major public health concern," Tech. Rep., World Health Organization, Geneva, Switzerland, 2010, (accessed January 2016), http://www.who.int/ipcs/ features/arsenic.pdf.

[56] US EPA, “Arsenic, inorganic," (accessed November 2016), https://cfpub.epa.gov/ncea/iris2/chemicalLanding.cfm?substance_nmbr=278.

[57] S. Bozhanov, I. Karadjova, and S. Alexandrov, "Determination of trace elements in the Lavender inflorescence (Lavandula angustifolia Mill.) -Lavender oil system," Microchemical Journal, vol. 86, no. 1, pp. 119-123, 2007.

[58] A. A. K. Abou-Arab and M. A. Abou Donia, "Heavy metals in Egyptian spices and medicinal plants and the effect of processing on their levels," Journal of Agricultural and Food Chemistry, vol. 48, no. 6, pp. 2300-2304, 2000.

[59] M. Senila, A. Drolc, A. Pintar, L. Senila, and E. Levei, "Validation and measurement uncertainty evaluation of the ICP-OES method for the multi-elemental determination of essential and nonessential elements from medicinal plants and their aqueous extracts," Journal of Analytical Science and Technology, vol. 5, no. 37, 2014.

[60] Institute of Medicine, Dietary Reference Intakes for Vitamin A, Vitamin K, Arsenic, Boron, Chromium, Copper, Iodine, Iron, Manganese, Molybdenum, Nickel, Silicon, Vanadium and Zinc, The National Academies Press, Washington, DC, USA, 2001, https://www.ncbi.nlm.nih.gov/books/NBK222310/pdf/Bookshelf_NBK222310.pdf.

[61] A. Łozak, K. Sołtyk, P. Ostapczuk, and Z. Fijałek, "Determination of selected trace elements in herbs and their infusions," Science of The Total Environment, vol. 289, no. 1-3, pp. 33-40, 2002.

[62] J. H. Kim, H. J. Gibb, and P. Howe, "Cobalt and Inorganic Cobalt Compounds," World Health Organization, http://www.who.int/ ipcs/publications/cicad/cicad69\%20.pdf.

[63] A. J. Baars, R. M. C. Theelen, P. J. C. M. Janssen et al., "Reevaluation of human-toxicological maximum permissible risk levels," RIVM Report, 2001, http://www.rivm.nl/bibliotheek/ rapporten/711701025.pdf.

[64] S. Başgel and S. B. Erdemoğlu, "Determination of mineral and trace elements in some medicinal herbs and their infusions consumed in Turkey," Science of the Total Environment, vol. 359, no. 1-3, pp. 82-89, 2006.

[65] L. Kékedy-Nagy and A. Ionescu, "Characterization and classification of tea herbs based on their metal content," Acta Universitatis Sapientiae, Agriculture and Environment, vol. 1, pp. 1119, 2009, (accessed October 2016), http://www.acta.sapientia.ro/ acta-agrenv/C1/agrenv12.pdf.

[66] E. Altintig, H. Altundag, and M. Tuzen, "Determination of multi element levels in leaves and herbal teas from Turkey by ICP-OES," Bulletin of the Chemical Society of Ethiopia, vol. 28, no. 1, pp. 9-16, 2014. 
[67] Directorate-General for Health and Food Safety European Commission, Assessment of the Tolerable Daily Intake of Barium, European Union, Brussels, Belgium, 2012.

[68] H. Matsumoto, E. Hirasawa, S. Morimura, and E. Takahashi, "Localization of aluminium in tea leaves," Plant and Cell Physiology, vol. 17, no. 3, pp. 627-631, 1976.

[69] B. Imelouane, M. Tahri, M. Elbastrioui, F. Aouinti, and A. Elbachiri, "Mineral contents of some medicinal and aromatic plants growing in eastern Morocco," Journal of Materials and Environmental Science, vol. 2, no. 2, pp. 104-111, 2013, (accessed November 2016), http://www.jmaterenvironsci.com/ Document/vol2/13-JMES-52-2010-Emelouane.pdf.

[70] A. Szymczycha-Madeja, M. Welna, and P. Pohl, "Elemental analysis of teas and their infusions by spectrometric methods," Trends in Analytical Chemistry, vol. 35, pp. 165-181, 2012.

[71] M. Kröppl, M. Zeiner, I. Juranovic Cindric, and G. Stingeder, "Differences in aluminium content of various tea powders (black, green, herbal, fruit) and tea infusions," European Chemical Bulletin, vol. 1, no. 9, pp. 382-386, 2012, (accessed December 2016), http://www.eurchembull.com/index.php/ECB/ article/view/110.

[72] A. Mehra and C. L. Baker, "Leaching and bioavailability of aluminium, copper and manganese from tea (Camellia sinensis)," Food Chemistry, vol. 100, no. 4, pp. 1456-1463, 2007.

[73] WHO, "Safety evaluation of certain food additives and contaminants," WHO Food Additives Series, World Health Organization, Geneva, Switzerland, 2012, (accessed June 2016), http://apps.who.int/iris/bitstream/10665/44813/1/9789241660655_eng.pdf.

[74] G. Schwalfenberg, S. J. Genuis, and I. Rodushkin, "The benefits and risks of consuming brewed tea: beware of toxic element contamination," Journal of Toxicology, vol. 2013, Article ID 370460, 8 pages, 2013.

[75] J. J. Powell, S. M. Greenfield, H. G. Parkes, J. K. Nicholson, and R. P. Thompson, "Gastro-intestinal availability of aluminium from tea," Food and Chemical Toxicology, vol. 31, no. 6, pp. 449454, 1993.

[76] R. A. Yokel and R. L. Florence, "Aluminum bioavailability from tea infusion," Food and Chemical Toxicology, vol. 46, no. 12, pp. 3659-3663, 2008.

[77] P. N. Drewitt, K. R. Butterworth, C. D. Springall, and S. R. Moorhouse, "Plasma levels of aluminium after tea ingestion in healthy volunteers," Food and Chemical Toxicology, vol. 31, no. 1, pp. 19-23, 1993.

[78] G. D. Gentscheva, T. Trajce Stafilov, and E. H. Ivanova, "Determination of some essential and toxic elements in herbs from Bulgaria and Macedonia using atomic spectrometry," Eurasian Journal of Analytical Chemistry, vol. 5, no. 2, pp. 104-111, 2010, http://www.iserjournals.com/journals/ejac/vol/5/issue/2.

[79] C. Lungu, A. Corciova, A. Spac, C. Ciobanu, B. Ivanescu, and B. Ivănescu, "Evaluation of bioactive compounds from commercial lavender products and comparative histo-anatomical study," Analele Stiintifice ale Universitatii "Al. I. Cuza" din Iasi, vol. 60, pp. 11-19, 2014, http://www.bio.uaic.ro/publicatii/anale_vegetala/issue/2014F2/02-2014F2.pdf.

[80] S. S. Ražić, S. M. Dogo, and L. J. Slavković, "Multivariate characterization of herbal drugs and rhizosphere soil samples according to their metallic content," Microchemical Journal, vol. 84, no. 1-2, pp. 93-101, 2006.

[81] P. Konieczynski and M. Wesolowski, "Water-extractable magnesium, manganese and copper in leaves and herbs of medicinal plants," Acta Poloniae Pharmaceutica-Drug Research, vol. 69, no. 1, pp. 33-39, 2012, (accessed October 2016), http://www .ptfarm.pl/pub/File/Acta_Poloniae/2012/1/033.pdf.

[82] WHO, "Manganese in drinking-water," Background Document for Development of WHO Guidelines for Drinking-Water Quality, World Health Organization, Geneva, Switzerland, 2011, (accessed June 2016), http://www.who.int/water_sanitation_ health/dwq/chemicals/manganese.pdf.

[83] P. Watts and P. Howe, Strontium and Strontium Compounds, World Health Organization, Geneva, Switzerland, 2010, (accessed December 2016), http://www.inchem.org/documents/cicads/cicads/cicad77.pdf.

[84] K. E. Ødegård and W. Lund, "Multi-element speciation of tea infusion using cation-exchangeseparation and size-exclusion chromatography in combination withinductively coupled plasma mass spectrometry," Journal of Analytical Atomic Spectrometry, vol. 12, no. 4, pp. 403-408, 1997.

[85] M. Dambiec, L. Polechońska, and A. Klink, "Levels of essential and non-essential elements in black teas commercialized in Poland and their transfer to tea infusion," Journal of Food Composition and Analysis, vol. 31, no. 1, pp. 62-66, 2013.

[86] V. R. Angelova, D. F. Grekov, V. K. Kisyov, and K. I. Ivanov, "Potential of lavender (Lavandula vera $L$.) for phytoremediation of soils contaminated with heavy metals," International Journal of Biological, Biomolecular, Agricultural, Food and Biotechnological Engineering, vol. 9, no. 5, pp. 522-529, 2015, http://waset .org/publications/10001414/potential-of-lavenderlavandula-vera-1.-for-phytoremediation-of-soilscontaminated-with-heavymetals.

[87] V. D. Zheljazkov, L. E. Craker, and B. Xing, "Effects of Cd, Pb, and $\mathrm{Cu}$ on growth and essential oil contents in dill, peppermint, and basil," Environmental and Experimental Botany, vol. 58, no. 1-3, pp. 9-16, 2006.

[88] A. A. Romeh, M. A. Khamis, and S. M. Metwally, "Potential of plantago major L. for phytoremediation of lead-contaminated soil and water," Water, Air, and Soil Pollution, vol. 227, no. 1, article 9, 2016.

[89] E. Masarovičová, K. Králová, and M. Kummerová, “Principles of classification of medicinal plants as hyperaccumulators or excluders," Acta Physiologiae Plantarum, vol. 32, no. 5, pp. 823829, 2010.

[90] V. D. Zheljazkov and N. E. Nielsen, "Studies on the effect of heavy metals $(\mathrm{Cd}, \mathrm{Pb}, \mathrm{Cu}, \mathrm{Mn}, \mathrm{Zn}$ and $\mathrm{Fe}$ ) upon the growth, productivity and quality of lavender (Lavandula angustifolia Mill.) production," Journal of Essential Oil Research, vol. 8, no. 3, pp. 259-274, 1996.

[91] D. Carpenter, C. Boutin, J. E. Allison, J. L. Parsons, and D. M. Ellis, "Uptake and effects of six rare earth elements (REEs) on selected native and crop species growing in contaminated soils," PLoS ONE, vol. 10, no. 6, Article ID e0129936, 2015.

[92] R. D. M. R. Gonçalves, L. S. Francisconi, and P. S. C. da Silva, "Rare earth elements determination in medicinal plants by neutron activation analysis," in Proceedings of the International Nuclear Atlantic Conference (INAC'13), Recife, PE, Brazil, 2013, http://www.iaea.org/inis/collection/NCLCollectionStore/_Public/46/015/46015560.pdf?r=1.

[93] S. H. Haneklaus, E. Schnug, B. G. Lottermoser, and Y. Hu, "Lanthanides", in Handbook of Plant Nutrition, A. V. Barker and D. J. Pilbeam, Eds., CRC Press, Boca Raton, Fla, USA, 2nd edition, 2015.

[94] A. Kabata-Pendias, Trace Elements in Soils and Plants, CRC Press, Boca Raton, Fla, USA, 4th edition, 2011. 
[95] M. R. Ganjali, V. K. Gupta, F. Faridbod, and P. Norouzi, Lanthanides Series Determination by Various Analytical Methods, Elsevier Inc, Amsterdam, Netherlands, 2016. 

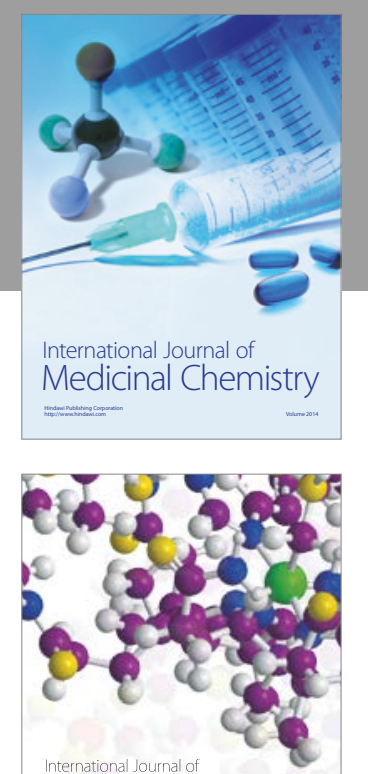

Carbohydrate Chemistry

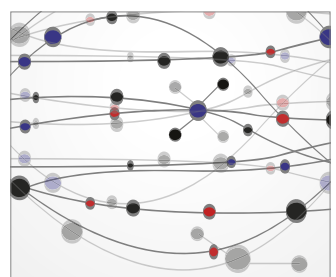

The Scientific World Journal
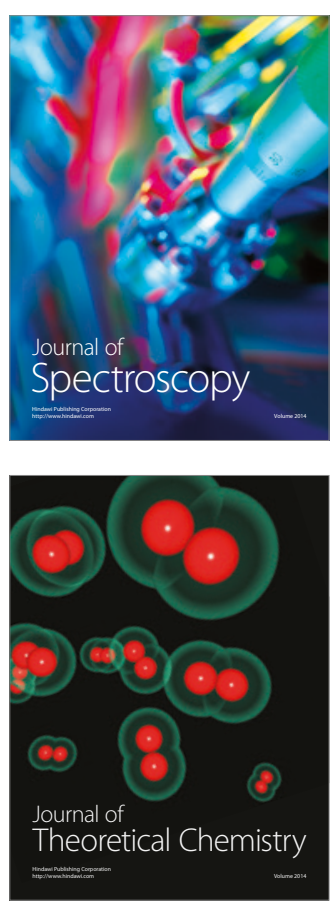
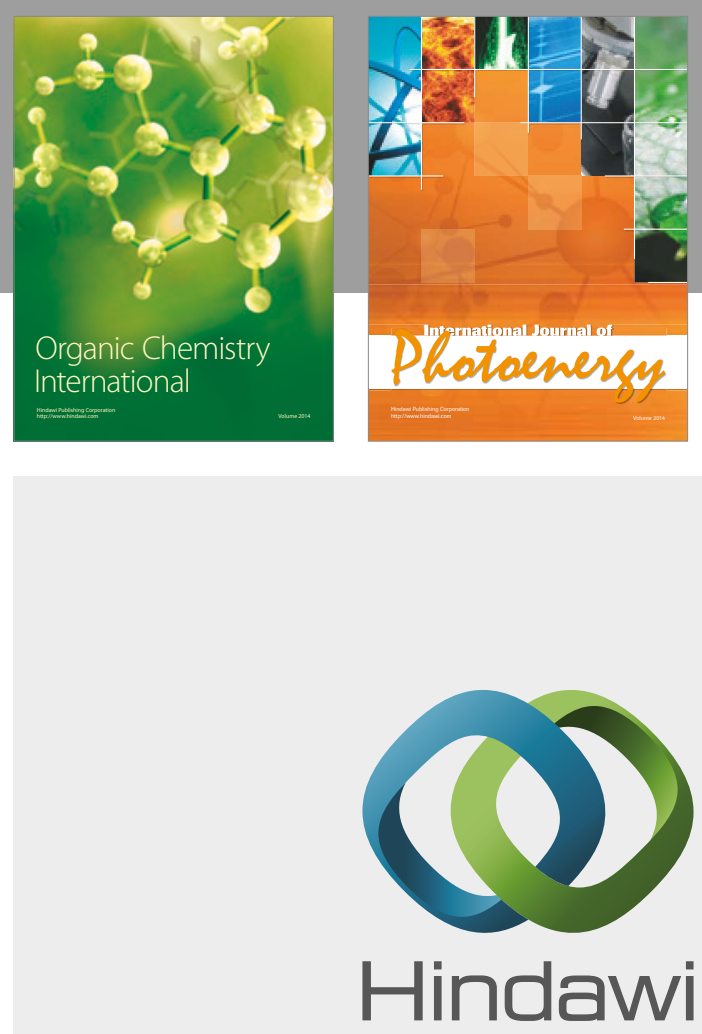

Submit your manuscripts at

https://www.hindawi.com

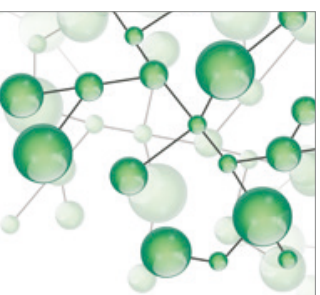

International Journal of

Inorganic Chemistry

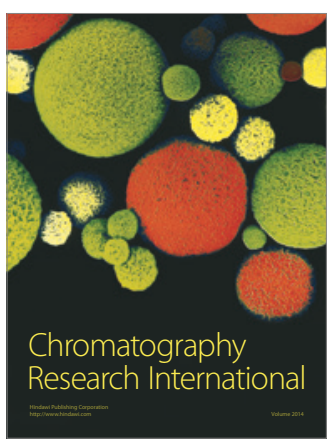

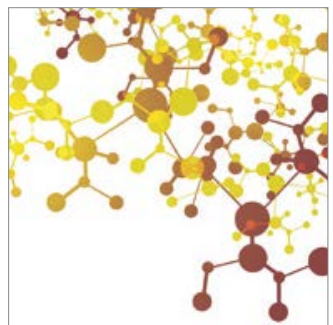

Applied Chemistry
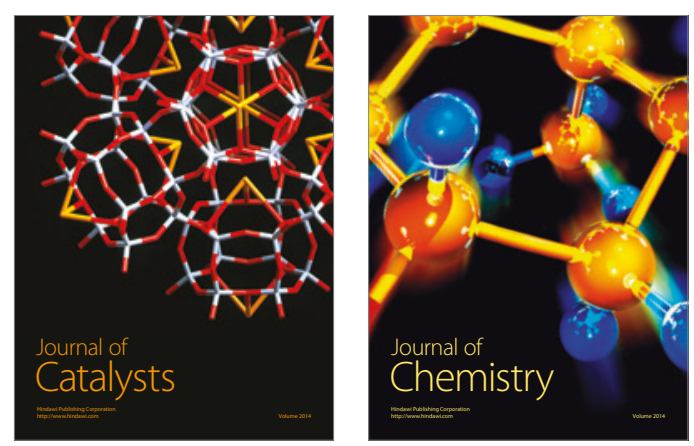
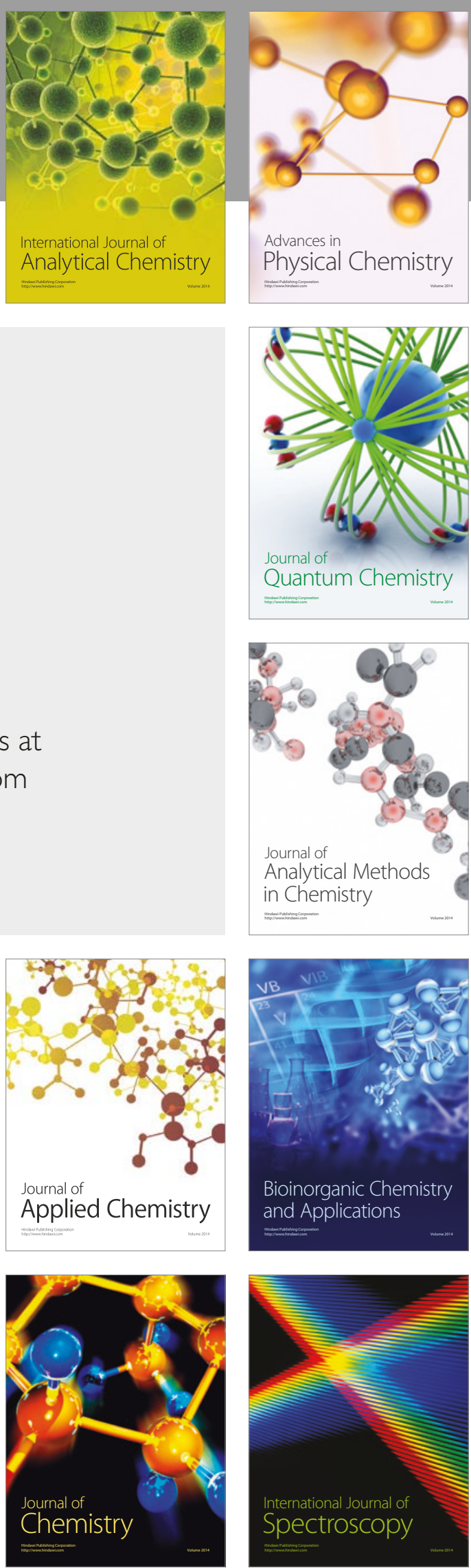